OPEN ACCESS

Edited by:

Leonard Peruski,

US Centers for Disease Control and Prevention, USA

Reviewed by:

Mark Hutchinson,

University of Maine, USA

Alistair Hugh Bishop,

Defence Science and Technology

Laboratory, UK

*Correspondence:

Tim A. McAllister

tim.mcallister@agr.gc.ca

tThese authors have contributed equally to this work.

Specialty section: This article was submitted to

Infectious Diseases,

a section of the journal

Frontiers in Microbiology

Received: 18 March 2016

Accepted: 12 May 2016

Published: 27 May 2016

Citation: Xu S, Harvey A, Barbieri R, Reuter T, Stanford K, Amoako KK, Selinger LB and McAllister TA (2016) Inactivation of Bacillus anthracis Spores during Laboratory-Scale Composting of Feedlot Cattle Manure.

Front. Microbiol. 7:806.

doi: 10.3389/fmicb.2016.00806

\section{Inactivation of Bacillus anthracis Spores during Laboratory-Scale Composting of Feedlot Cattle Manure}

\author{
Shanwei $\mathrm{Xu}^{1+}$, Amanda Harvey ${ }^{1,2 t}$, Ruth Barbieri' ${ }^{1}$, Tim Reuter $^{3}$, Kim Stanford ${ }^{3}$, \\ Kingsley K. Amoako ${ }^{4}$, Leonard B. Selinger ${ }^{2}$ and Tim A. McAllister ${ }^{1 *}$
}

${ }^{1}$ Lethbridge Research and Develeopment Centre, Agriculture and Agri-Food Canada, Lethbridge, AB, Canada, ${ }^{2}$ Department of Biological Sciences, University of Lethbridge, Lethbridge, AB, Canada, ${ }^{3}$ Alberta Agriculture and Forestry, Lethbridge, AB, Canada, ${ }^{4}$ Lethbridge Laboratory, Canadian Food Inspection Agency, National Centres for Animal Disease, Lethbridge, $A B$, Canada

Anthrax outbreaks in livestock have social, economic and health implications, altering farmer's livelihoods, impacting trade and posing a zoonotic risk. Our study investigated the survival of Bacillus thuringiensis and $B$. anthracis spores sporulated at 15,20 , or $37^{\circ} \mathrm{C}$, over 33 days of composting. Spores $\left(\sim 7.5 \log _{10} \mathrm{CFU} \mathrm{g}^{-1}\right)$ were mixed with manure and composted in laboratory scale composters. After 15 days, the compost was mixed and returned to the composter for a second cycle. Temperatures peaked at $71^{\circ} \mathrm{C}$ on day 2 and remained $\geq 55^{\circ} \mathrm{C}$ for an average of 7 days in the first cycle, but did not exceed $55^{\circ} \mathrm{C}$ in the second. For $B$. thuringiensis, spores generated at 15 and $21^{\circ} \mathrm{C}$ exhibited reduced $(P<0.05)$ viability of 2.7 and $2.6 \log _{10} \mathrm{CFU} \mathrm{g} \mathrm{g}^{-1}$ respectively, as compared to a $0.6 \log _{10} \mathrm{CFU} \mathrm{g} g^{-1}$ reduction for those generated at $37^{\circ} \mathrm{C}$. For B. anthracis, sporulation temperature did not impact spore survival as there was a 2.5, 2.2, and $2.8 \log _{10} \mathrm{CFU} \mathrm{g} \mathrm{g}^{-1}$ reduction after composting for spores generated at 15,21 , and $37^{\circ} \mathrm{C}$, respectively. For both species, spore viability declined more rapidly $(P<0.05)$ in the first as compared to the second composting cycle. Our findings suggest that the duration of thermophilic exposure $\left(\geq 55^{\circ} \mathrm{C}\right)$ is the main factor influencing survival of $B$. anthracis spores in compost. As sporulation temperature did not influence survival of $B$. anthracis, composting may lower the viability of spores associated with carcasses infected with $B$. anthracis over a range of sporulation temperatures.

Keywords: Bacillus anthracis, spore, sporulation, compost, anthrax, temperature

\section{INTRODUCTION}

Anthrax is a lethal mammalian disease, capable of infecting animals and humans and remains an ongoing global problem (Spencer, 2003; Sternbach, 2003). Before the development of a vaccine for the treatment of livestock in the 1870's, anthrax was one of the leading causes of worldwide mortality in cattle, goats, horses, and sheep (Hugh-Jones and Blackburn, 2009). During the past 20 years, even with the availability of a vaccine, human anthrax is still a significant problem in

Abbreviations: TC, total carbon; TN, total nitrogen; EC, electrical conductivity. 
Western Africa, Eastern Europe, and Central Asia, with sporadic outbreaks continuing to occur in livestock in the United States and Canada (Levin, 2014).

The causative agent of anthrax is Bacillus anthracis, a Grampositive, aerobic, endospore forming rod-shaped bacterium (World Health Organization, 2008). Spores are the primary infectious form of $B$. anthracis with infection occurring through ingestion, inhalation or cutaneous exposure (Thappa and Karthikeyan, 2001). Bacillus spores are resistant to heat, desiccation, radiation and chemical treatment (Stephens, 1998) so decontamination can be a challenge. It has been reported that Bacillus spores can persist in soil for at least 300 years (Nicholson et al., 2000). The infectious dose of B. anthracis spores varies among host species and with route of infection. As few as ten inhaled B. anthracis spores are sufficient to cause infection in cattle and sheep (Smith, 1973), while 500-55,000 inhaled spores is the estimated range for a lethal dose for humans (Wallin et al., 2007).

In Canada, there is still a concern with repeated outbreaks of anthrax in wild bison populations in the Northwest Territories, Northern Alberta, Manitoba, and Saskatchewan (Beaumont, 2013; Elkin et al., 2013). Moreover, an anthrax outbreak occurred in Saskatchewan in 2006, resulting in the death of 804 livestock (Himsworth and Argue, 2008). Proper disposal of animal carcasses infected with $B$. anthracis is essential to minimize spore contamination and reduce the risk of transmission to animals and humans. In addition, the extreme virulence, environmental persistence and multiple routes of infection have also resulted in anthrax spores being employed as a biological weapon (Ala'Aldeen, 2001; Cole, 2010). Therefore, in the event of a natural or a terror related outbreak of $B$. anthracis, proper technologies are required to inactivate spores associated with contaminated livestock carcasses.

In Canada, current disposal practices approved by Canadian Food Inspection Agency (CFIA) for B. anthracis infected carcasses include incineration and deep burial with chemical treatment using $10 \%$ formalin or 5\% sodium hydroxide (CFIA, 2013). However, Canada's vast geographical area and transportation distances frequently make incineration impractical as a disposal method. Moreover, deep burial can render the disposal site a long-term reservoir of spores with heavy rain fall and soil saturation promoting renewed transmission as viable spores migrate to the soil surface (Nicholson, 2002; Himsworth and Argue, 2008). Composting may offer a practical and economical means for the safe disposal of carcasses during an anthrax outbreak. Composting is an aerobic decomposition process whereby organic matter is degraded by the actions of mesophilic and thermophilic bacteria and fungi. Compost is often alkaline $(\mathrm{pH} \mathrm{8-10)}$ as a result of the liberation of ammonia from the deamination of amino acids and temperatures can reach $\sim 70^{\circ} \mathrm{C}$ and exceed $55^{\circ} \mathrm{C}$ for weeks or even months (Xu et al., 2009; Stanford et al., 2015). These conditions have been shown to inactivate most microbial pathogens including Listeria (Erickson et al., 2009a), Shiga-toxigenic Escherichia coli (Xu et al., 2009), Salmonella (Erickson et al., 2009b), Giardia, Cryptosporidium (Van Herk et al., 2004), and avian influenza, Newcastle disease and foot-and-mouth disease viruses (Guan et al., 2009, 2010). Even recalcitrant proteins such as the prions associated with scrapie, chronic wasting disease (CWD) and bovine spongiform encephalopathy (BSE) are degraded during composting (Xu et al., 2014).

Our research group has previously used related sporeforming bacteria (i.e., B. licheniformis, B. thuringiensis, and $B$. cereus) as surrogates for investigating the inactivation of $B$. anthracis in compost under field conditions (Reuter et al., 2011; Stanford et al., 2015). To further define the feasibility of composting for disposal of $B$. anthracis infected carcasses, assessment of the fate of $B$. anthracis spores in compost is required. However, such studies with $B$. anthracis can only be safely conducted under full laboratory containment, conditions that we have met using specially designed laboratory-scale composters (Xu et al., 2010). Our recent findings have shown that sporulation temperature was a key factor influencing survival of $B$. cereus spores in cattle carcass compost (Stanford et al., 2015). Therefore, the objective of this study was to assess the survival of $B$. anthracis spores generated at different sporulation temperatures $\left(15,21\right.$, or $\left.37^{\circ} \mathrm{C}\right)$ using laboratory composters in containment.

\section{MATERIALS AND METHODS}

\section{Laboratory Composting Experiment}

Passively aerated laboratory-scale composters were used as described by $\mathrm{Xu}$ et al. (2010). These 110-L cylindrical polyethylene vessels were sealed and insulated with a $50 \mathrm{~mm}$ layer of polyurethane foam. For the purpose of passive aeration, an air plenum ( $0.1 \mathrm{~m}$ height) was created at the bottom of each composter using a perforated polyethylene panel with $10 \mathrm{~mm}$ diameter holes. Inlet and outlet air holes $(25 \mathrm{~mm})$ were drilled in the side, near the bottom and in the lid to enable passive aeration. Fresh feedlot manure ( $45 \pm 0.1 \mathrm{~kg}$; wetweight basis) and white spruce (Picea glauca) wood shavings $(4.5 \pm 0.1 \mathrm{~kg})$ were thoroughly mixed in a mortar mixer (12S; Crown construction equipment, Winnipeg, MB, Canada) to form a matrix with a moisture content of $76.0 \pm 0.3 \%$. The physicochemical properties of the ingredients are described in Table 1. Spores of B. anthracis and its surrogate B. thuringiensis were composted in a level 3 biocontainment laboratory at the CFIA in Lethbridge, $\mathrm{AB}$ (Figure 1). Prior to the compost experiment, the lab benches and floors were swab-tested to ensure they were not contaminated with Bacillus spores. Identical matrices without inoculation with Bacillus spores were composted outside of containment with samples being collected for measurement of physicochemical parameters during the composting process. Experiments inside and outside of containment were started simultaneously with four replicated composters outside containment and two replicated composters for each Bacillus species inside containment (Figure 1).

\section{Spore Preparation}

The strain of $B$. anthracis Sterne was kindly provided by Dr. Elizabeth Golsteyn Thomas (CFIA) and Mr. Doug 
TABLE 1 | Physicochemical characteristics of materials included in matrices used for laboratory composting under both non-containment and containment conditions.

\begin{tabular}{lcc}
\hline Parameters* & Cattle manure & Wood shavings \\
\hline Moisture (\%) & $81.1 \pm 0.5$ & $9.6 \pm 0.0$ \\
Bulk density $\left(\mathrm{kg} \mathrm{m}^{-3}\right)$ & $854 \pm 6$ & $88 \pm 1$ \\
Total carbon (\%) & $41.8 \pm 0.9$ & $51.4 \pm 0.6$ \\
Total nitrogen (\%) & $2.19 \pm 0.07$ & $0.08 \pm 0.00$ \\
$\mathrm{C} / \mathrm{N}$ ratio & $19.1 \pm 0.3$ & $662.2 \pm 27.5$ \\
$\mathrm{pH}$ & $7.99 \pm 0.16$ & $4.87 \pm 0.03$ \\
$\mathrm{EC}\left(\mathrm{ds} \mathrm{m}^{-1}\right)$ & $1.16 \pm 0.06$ & $0.05 \pm 0.00$ \\
$\mathrm{NH}_{4}-\mathrm{N}\left(\mathrm{mg} \mathrm{kg}^{-1}\right)$ & $4237 \pm 500$ & $3 \pm 1$ \\
$\left(\mathrm{NO}_{2}+\mathrm{NO}_{3}\right)-\mathrm{N}\left(\mathrm{mg} \mathrm{kg}^{-1}\right)$ & $40.1 \pm 5.2$ & $6.2 \pm 0.0$
\end{tabular}

*All parameters except moisture and bulk density are expressed on a dry-weight basis $\left(w w^{-1}\right)$. Moisture and bulk density are expressed on a wet-weight basis. EC, electrical conductivity.

Bader (Defence Research Development Canada) with NCBI Genome Reference Sequence of NC_005945.1(pXO2-), while B. thuringiensis $4 \mathrm{~A} 3$ was provided by Dr. Tim Lysyk (Agriculture and Agri-Food Canada, Lethbridge Research Centre). Spores of $B$. anthracis Sterne and $B$. thuringiensis $4 \mathrm{~A} 3$ were prepared from triplicate overnight cultures of single discrete colonies as previously described by Reuter et al. (2011) and Shields et al. (2012), respectively. Briefly, $100 \mu \mathrm{l}$ of the overnight culture was used to inoculate culture flasks containing $50 \mathrm{ml}$ of tryptic soy agar [Becton Dickinson (BD), Franklin Lakes, NJ, USA) supplemented with $5 \%$ sheep blood for $B$. anthracis or AK number 2 agar (BD) supplemented with $20 \mu \mathrm{g} \mathrm{ml}^{-1} \mathrm{MgSO}_{4}$ and $80 \mu \mathrm{g} \mathrm{ml}^{-1} \mathrm{CaCl}_{2}$ for $B$. thuringiensis. Flasks were incubated at either 15,21 , or $37^{\circ} \mathrm{C}$ for 8 days until sporulation was complete. Spores were harvested by dispensing phosphate buffered saline (PBS) containing 0.05\% Tween 20 (PBST; Sigma-Aldrich, St. Louis, MO, USA) into each flask with gentle mixing in the presence of glass beads to suspend the spores. Suspensions were transferred into $50 \mathrm{ml}$ Falcon tubes and centrifuged at 6,000 $\times g$ for $10 \mathrm{~min}$ at $4^{\circ} \mathrm{C}$ to pellet the spores. The supernatant was discarded, and the pellets were washed five times with PBST. After the last wash, pellets were resuspended in 50\% ethanol and centrifuged as described above to remove all remaining vegetative cells. After washing, a droplet of the suspension was examined using phase-contrast microscopy to ensure that cellular debris and vegetative cells were removed. For each Bacillus species, spores generated at each temperature were re-suspended in PBS with $1 \%$ bovine serum albumin (BSA; Sigma-Aldrich) and then serially diluted (1:10) for estimating spore CFU as described by Reuter et al. (2011) and Shields et al. (2012).

\section{Nylon Bag Preparation}

Due to the high concentration of Bacillus spores in feedlot manure compost matrix, generated spores were inoculated into feces collected directly from the rectum of cattle. The feces had physicochemical properties that were similar to the feedlot manure used in compost, but reduced background microflora for the subsequent detection of Bacillus spores (data not shown).
Feces (5.0 $\pm 0.1 \mathrm{~g}$; wet basis) was shaped into spheres and then inoculated with Bacillus spore suspensions to achieve $\sim 7.5 \log _{10}$ $\mathrm{CFU} \mathrm{g} \mathrm{g}^{-1}$ manure for each sporulation temperature and Bacillus species. However, a lower concentration of $B$. thuringiensis spores

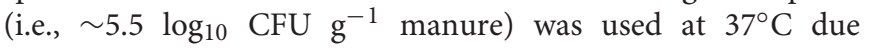
to reduced yield, a response that has been observed for this species when it was sporulated by others at $40^{\circ} \mathrm{C}$ (Ignatenko et al., 1983). Inoculated manure spheres were sealed in nylon bags $(5 \times 10 \mathrm{~cm} ; 53 \mu \mathrm{m}$ pore size; ANKOM Technology, Macedon, NY, USA) prior to placing into composters. For controls, $3 \mathrm{~g}$ of autoclaved $\left(121^{\circ} \mathrm{C}, 20 \mathrm{~min}\right)$ silica beads $(4 \mathrm{~mm}$; Fisher Scientific, Ottawa, ON, Canada) were inoculated with spore suspensions to achieve the same spore concentration as in manure and then sealed in a sterile $50 \mathrm{ml}$ Falcon tube. Controls of nylon bags containing inoculated manure spheres and tubes containing inoculated silica beads were both retained at room temperature during the experimental period. Duplicate control nylon bags and tubes for each sporulation temperature and Bacillus species were collected at each sampling day (Figure 1). Nylon bags were prepared on the day of compost construction and implanted into compost immediately after the compost was prepared.

\section{Nylon Bag Implantation and Sampling Procedures}

For each sporulation temperature and Bacillus species, two replicate nylon bags were placed in a larger polyester mesh bag (5 mm pore size) along with $200 \mathrm{~g}$ of freshly mixed compost. As each composter was filled, four replicate mesh bags for each sporulation temperature were placed at a depth of $30 \mathrm{~cm}$ below the surface of the compost matrix, resulting in a total of twelve mesh bags in each composter. Single mesh bags for each sporulation temperature were collected from each composter after 8 and 15 days of composting (Figure 1). A total of three mesh bags were removed at each sampling time per replicate composter (Figure 1). After collection at day 15, each composter was emptied, and contents were mixed with water to return the compost to its original moisture level. Compost was then returned to its original composter for a second heating cycle. As the composters were refilled, the remaining mesh bags were placed in each composter at the same depth as in the first cycle. In the second composting cycle, mesh bags were collected after 22 and 33 days (Figure 1). Compost temperature was continuously measured at the same depth as the mesh bags were implanted (Xu et al., 2010). Composters outside of containment were managed similarly, except that the manure implanted in the compost matrix was not inoculated with Bacillus spores. The experiment was designed in this manner as compost within the composters in containment could not be removed from the containment laboratory for chemical analysis.

Compost in each composter outside of containment was collected at day 15 after mixing and moistening, and also from each of the mesh bags for physicochemical analyses. Compost temperatures, oxygen concentration, moisture, bulk density, TC, TN, pH, EC, and mineral $\mathrm{N}\left(\mathrm{NH}_{4}{ }^{+}\right.$and $\left.\mathrm{NO}_{2}{ }^{-}+\mathrm{NO}_{3}{ }^{-}\right)$were measured (Xu et al., 2010). 


\begin{tabular}{|c|c|c|c|c|c|c|c|}
\hline & & & \multicolumn{5}{|c|}{ Sampling days } \\
\hline & & & Day 0 & Day 8 & Day 15 & Day 22 & Day 33 \\
\hline & Species & $\begin{array}{l}\text { Sporulation } \\
\text { temperatures }\end{array}$ & \multicolumn{5}{|c|}{$\begin{array}{c}\text { Numbers of nylon bags and silica bead } \\
\text { tubes collected }\end{array}$} \\
\hline \multirow{3}{*}{ Composter 1} & \multirow{3}{*}{$\begin{array}{c}B . \\
\text { thuringiensis }\end{array}$} & $15^{\circ} \mathrm{C}$ & 2 & 2 & 2 & 2 & 2 \\
\hline & & $21^{\circ} \mathrm{C}$ & 2 & 2 & 2 & 2 & 2 \\
\hline & & $37^{\circ} \mathrm{C}$ & 2 & 2 & 2 & 2 & 2 \\
\hline \multirow{3}{*}{ Composter 2} & \multirow{3}{*}{$\begin{array}{c}\text { B. } \\
\text { thuringiensis }\end{array}$} & $15^{\circ} \mathrm{C}$ & 2 & 2 & 2 & 2 & 2 \\
\hline & & $21^{\circ} \mathrm{C}$ & 2 & 2 & 2 & 2 & 2 \\
\hline & & $37^{\circ} \mathrm{C}$ & 2 & 2 & 2 & 2 & 2 \\
\hline \multirow{3}{*}{ Composter 3} & \multirow{3}{*}{ B. anthracis } & $15^{\circ} \mathrm{C}$ & 2 & 2 & 2 & 2 & 2 \\
\hline & & $21^{\circ} \mathrm{C}$ & 2 & 2 & 2 & 2 & 2 \\
\hline & & $37^{\circ} \mathrm{C}$ & 2 & 2 & 2 & 2 & 2 \\
\hline \multirow{3}{*}{ Composter 4} & \multirow{3}{*}{ B. anthracis } & $15^{\circ} \mathrm{C}$ & 2 & 2 & 2 & 2 & 2 \\
\hline & & $21^{\circ} \mathrm{C}$ & 2 & 2 & 2 & 2 & 2 \\
\hline & & $37^{\circ} \mathrm{C}$ & 2 & 2 & 2 & 2 & 2 \\
\hline \multirow{6}{*}{$\begin{array}{c}\text { Room } \\
\text { Temperature } \\
\text { Control }\end{array}$} & \multirow{3}{*}{$\begin{array}{c}B . \\
\text { thuringiensis }\end{array}$} & $15^{\circ} \mathrm{C}$ & 4 & 4 & 4 & 4 & 4 \\
\hline & & $21^{\circ} \mathrm{C}$ & 4 & 4 & 4 & 4 & 4 \\
\hline & & $37^{\circ} \mathrm{C}$ & 4 & 4 & 4 & 4 & 4 \\
\hline & \multirow{3}{*}{ B. anthracis } & $15^{\circ} \mathrm{C}$ & 4 & 4 & 4 & 4 & 4 \\
\hline & & $21^{\circ} \mathrm{C}$ & 4 & 4 & 4 & 4 & 4 \\
\hline & & $37^{\circ} \mathrm{C}$ & 4 & 4 & 4 & 4 & 4 \\
\hline & & & \multicolumn{2}{|c|}{ Total } & \multicolumn{3}{|c|}{180 bags and 60 tubes } \\
\hline & & & \multicolumn{2}{|c|}{ Total per day } & \multicolumn{3}{|c|}{36 bags and 12 tubes } \\
\hline
\end{tabular}

FIGURE 1 | Schematic representation of the experimental design and numbers of Bacillus thuringiensis and B. anthracis samples collected during composting under biocontainment conditions. Duplicated composters were used for each Bacillus species sporulated at 15,21 , and $37^{\circ} \mathrm{C}$. Manure was inoculated with spore suspensions and then sealed in nylon bags prior to placing into composters. For a room temperature control, autoclaved silica beads were inoculated to achieve the same spore concentration as for inoculation of manure and then sealed in Falcon tubes. Two replicate nylon bags for each sporulation temperature and species were collected from the composters at days $0,8,15,22$, and 33. Room temperature controls of duplicate nylon bags and tubes (i.e., total number $=4$ ) for each sporulation temperature and species were collected on the same sampling day.

\section{Enumeration of Bacillus thuringiensis and Bacillus anthracis}

Upon removal of mesh bags from compost, nylon bags were removed from mesh bags and enclosed within a water-tight container. At each sampling day, controls of silica bead tubes and nylon bags retained at room temperatures were also sealed within double packaged Ziplock bags (SC Johnson, Racine, WI, USA). Subsequently, all sealed cups and bags were submerged in bleach (10\%) for $30 \mathrm{~min}$ and retained within the containment laboratory for enumeration of Bacillus spores. Nylon bags of each Bacillus species were placed into sterile stomacher bags containing $45 \mathrm{ml}$ 
PBS and blended for $2 \mathrm{~min}$ in a Stomacher 400 (Seward, Davie, $\mathrm{Fl}, \mathrm{USA}$ ) at $230 \mathrm{rpm}$. A $5 \mathrm{ml}$ aliquot was transferred to a $15 \mathrm{ml}$ Falcon tube and incubated at $75^{\circ} \mathrm{C}$ for $20 \mathrm{~min}$ in a shaking water bath. After cooling, a $100 \mu \mathrm{l}$ aliquot was serially diluted $\left(10^{-1}\right.$ $10^{-5}$ ) into PBS and plated onto duplicate blood tryptic soy agar plates. For silica bead samples, $30 \mathrm{ml}$ of PBS were added into each $50 \mathrm{ml}$ Falcon tube containing the beads and then mixed using a serological pipet. A $5 \mathrm{ml}$ aliquot was then transferred to a $15 \mathrm{ml}$ Falcon tube. The tubes were heat treated, serially diluted and plated as described for nylon bags. Colonies on the plates were enumerated after incubation at $37^{\circ} \mathrm{C}$ for $16-18 \mathrm{~h}$, and only plates that contained 30 to $300 \mathrm{CFU}$ were counted. The quantification limit was set at $\geq 30 \mathrm{CFU}$ in the first dilution $\left(10^{-1}\right)$. Numbers of $B$. thuringiensis and $B$. anthracis spores were calculated as CFU per $g$ of the original weight of manure in the nylon bags or silica beads.

\section{Statistical Analysis}

Numbers of $B$. thuringiensis and B. anthracis spores were log transformed before analysis. Changes in the spore number for each Bacillus species and temperature profiles during biocontainment composting were analyzed using the MIXED Procedure of SAS (Version 9.2; SAS Institute Inc., Cary, NC, USA) with time treated as a repeated measure in the model. Main effects of sampling day, sporulation temperature and their interaction were considered to be statistically significant at a probability level of $<0.05$.

\section{RESULTS}

\section{Compost Properties}

Under biocontainment, compost temperatures for each Bacillus species were affected $(P<0.05)$ by composting cycle. All the composters heated rapidly, with temperatures peaking after 2 days at $72^{\circ} \mathrm{C}$ for composters containing $B$. anthracis and $70^{\circ} \mathrm{C}$ for those containing $B$. thuringiensis (Figure 2A). Subsequently, temperatures steadily declined, but increased again and peaked at $61^{\circ} \mathrm{C}$ for B. anthracis at day 10 and $57^{\circ} \mathrm{C}$ for $B$. thuringiensis at day 9. During the first composting cycle, temperature remained above $55^{\circ} \mathrm{C}$ for 8 and 5 days for $B$. anthracis and B. thuringiensis, respectively (Figure 2A). After mixing and moistening of compost on day 15, temperatures did not exceed $55^{\circ} \mathrm{C}$ and peaked at $53^{\circ} \mathrm{C}$ on day 17 for both $B$. anthracis and $B$. thuringiensis (Figure 2A), which were lower $(P<0.05)$ than the peak temperatures measured in the first cycle.

Compost temperature in containment (Figure 2A) mirrored that obtained outside of containment (Figure 2B) which was used to assess changes in physicochemical parameters during composting. Oxygen concentration was $1 \%$ in compost at day 0 (Figure 2C) and then increased to $15 \%$ after 5 days, and remained between 15 and 19\% until the end of experiment (Figure 2C). During the two cycles of composting, moisture content consistently remained in the range of $74-77 \%$ (wet weight basis; Table 2). Levels of TC, $\mathrm{C} / \mathrm{N}$ ratio, $\mathrm{NH}_{4}{ }^{+}-\mathrm{N}$, and $\left(\mathrm{NO}_{2}{ }^{-}+\mathrm{NO}_{3}{ }^{-}\right)-\mathrm{N}$ steadily declined over each composting
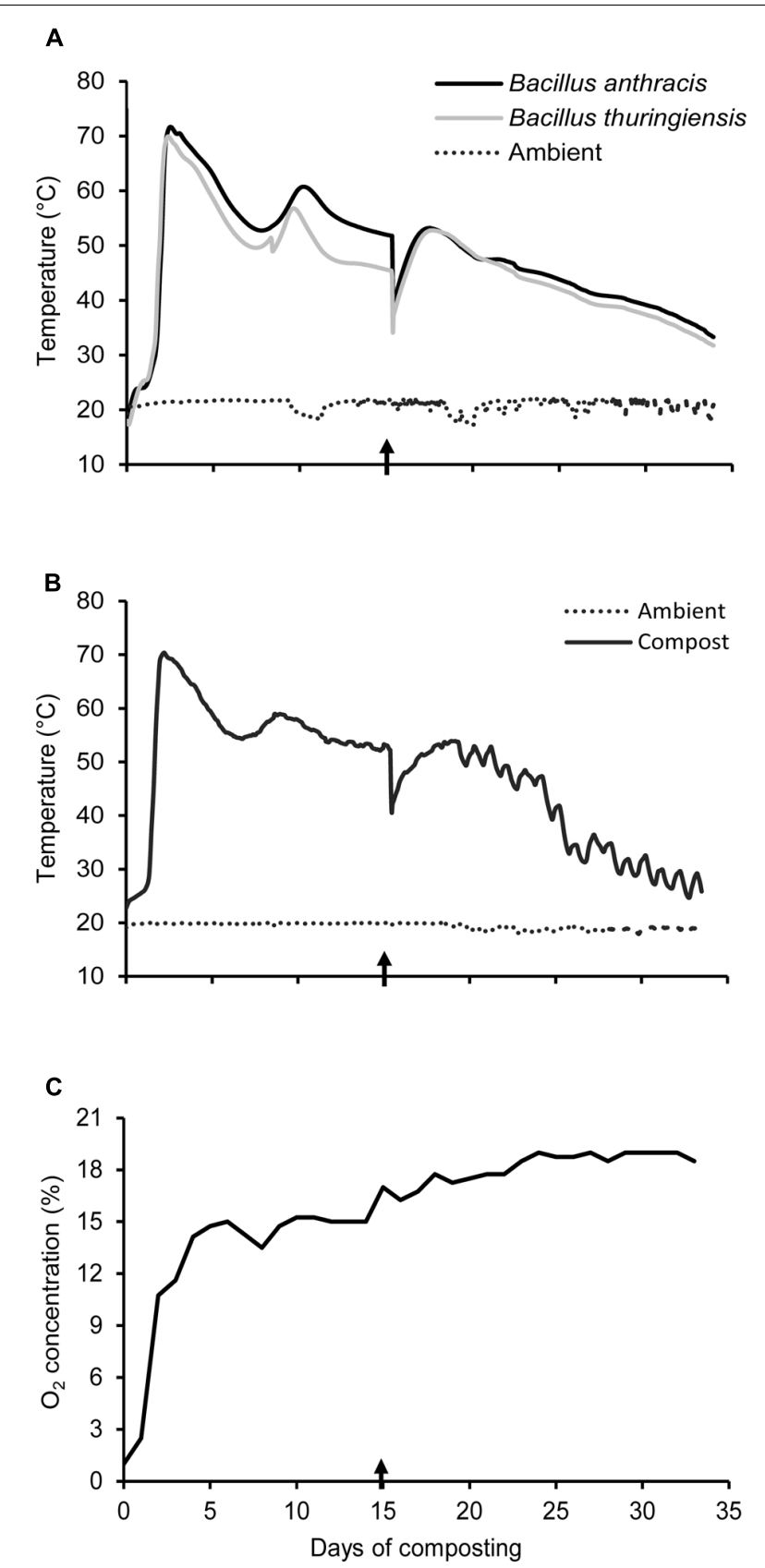

FIGURE 2 | (A) Temperature during composting of feedlot cattle manure containing $B$. thuringiensis and $B$. anthracis spores under containment, and (B) temperature and (C) $\mathrm{O}_{2}$ concentration during composting of feedlot cattle manure outside of containment. Arrows indicate the date when compost was mixed and moistened.

cycle, whereas TN tended to increase (Table 2). The $\mathrm{pH}$ was 7.7 at the start of composting, and increased to 9.1 and 9.3 after the first and second composting cycle, respectively (Table 2). Both compost EC and bulk density gradually declined during the initial composting cycle. However, compost EC remained the same whereas bulk density increased over the second cycle (Table 2). 
TABLE 2 | Physicochemical changes of compost mixtures during laboratory-scale composting.

\begin{tabular}{|c|c|c|c|c|c|c|}
\hline Parameters* & Day 0 & Day 8 & Day 15 (Before mixing) & Day 15 (After mixing) & Day 22 & Day 33 \\
\hline Moisture (\%) & $75.1 \pm 0.6$ & $75.2 \pm 1.7$ & $74.3 \pm 1.4$ & $77.6 \pm 0.5$ & $76.7 \pm 1.1$ & $77.0 \pm 1.0$ \\
\hline Total carbon (\%) & $46.1 \pm 0.3$ & $45.3 \pm 0.3$ & $44.8 \pm 0.2$ & $44.9 \pm 0.5$ & $43.7 \pm 0.3$ & $42.6 \pm 0.6$ \\
\hline Total nitrogen (\%) & $1.40 \pm 0.02$ & $1.57 \pm 0.05$ & $1.53 \pm 0.03$ & $1.63 \pm 0.04$ & $1.82 \pm 0.03$ & $2.20 \pm 0.05$ \\
\hline $\mathrm{C} / \mathrm{N}$ ratio & $33.0 \pm 0.5$ & $29.0 \pm 1.2$ & $29.4 \pm 0.6$ & $27.7 \pm 0.9$ & $24.1 \pm 0.6$ & $19.4 \pm 0.6$ \\
\hline $\mathrm{pH}$ & $7.65 \pm 0.06$ & $8.84 \pm 0.03$ & $9.11 \pm 0.03$ & $8.92 \pm 0.02$ & $9.17 \pm 0.04$ & $9.25 \pm 0.03$ \\
\hline$E C\left(d s m^{-1}\right)$ & $1.02 \pm 0.05$ & $0.63 \pm 0.09$ & $0.63 \pm 0.09$ & $0.66 \pm 0.07$ & $0.66 \pm 0.07$ & $0.66 \pm 0.10$ \\
\hline $\mathrm{NH}_{4}-\mathrm{N}\left(\mathrm{mg} \mathrm{kg}^{-1}\right)$ & $2514 \pm 15$ & $1229 \pm 296$ & $1274 \pm 198$ & $1163 \pm 64$ & $429 \pm 156$ & $192 \pm 68$ \\
\hline$\left(\mathrm{NO}_{2}+\mathrm{NO}_{3}\right)-\mathrm{N}\left(\mathrm{mg} \mathrm{kg}^{-1}\right)$ & $33.5 \pm 7.8$ & $10.3 \pm 3.4$ & $8.4 \pm 2.3$ & $12.6 \pm 9.5$ & $1.9 \pm 0.7$ & $3.4 \pm 0.8$ \\
\hline Bulk density $\left(\mathrm{kg} \mathrm{m}^{-3}\right)$ & $491 \pm 7$ & $481 \pm 17$ & $471 \pm 19$ & $552 \pm 19$ & $559 \pm 19$ & $573 \pm 21$ \\
\hline
\end{tabular}

${ }^{*}$ All parameters except moisture and bulk density are expressed on a dry-weight basis $\left(w w^{-1}\right)$. Moisture and bulk density are expressed on a wet-weight basis. EC, electrical conductivity.

\section{Survival of Bacillus thuringiensis Spores}

For controls, B. thuringiensis spores generated at all three temperatures remained relatively stable within the silica beads and manure at room temperature, only declining by $0-0.3$ $\log _{10}$ CFU g $g^{-1}$ over 33 days (Figure 3). During two cycles of composting, viability of $B$. thuringiensis spores sporulated at 15 and $21^{\circ} \mathrm{C}$ exhibited a similar reduction of 2.7 and 2.6 $\log _{10} \mathrm{CFU} \mathrm{\textrm {g } ^ { - 1 }}$, respectively (Figures 3A,B). This reduction was more $(P<0.05)$ pronounced in the first than the second composting cycle (Figures 3A,B). Overall, the reduction in viability of spores generated at $37^{\circ} \mathrm{C}$ averaged $0.6 \log _{10} \mathrm{CFU}$ $\mathrm{g}^{-1}$ after two cycles of composting (Figure 3C), which was lower than $(P<0.05)$ those sporulated at either 15 or $21^{\circ} \mathrm{C}$ (Figures 3A,B).

\section{Survival of Bacillus anthracis Spores}

Spores of B. anthracis generated at all three sporulation temperatures remained virtually stable in the control silica beads stored at room temperature over 33 days (Figure 4). In contrast, spore viability decreased by $0.4-0.6 \log _{10} \mathrm{CFU} \mathrm{g}^{-1}$ in the control manure over the same time period (Figure 4). Composting reduced the number of viable spores compared to inoculated control samples held at room temperature. However, sporulation temperature exerted no effect on the survival of $B$. anthracis spores in compost (Figure 4). The numbers of viable spores generated at 15,21 , and $37^{\circ} \mathrm{C}$ declined by $2.2,1.5$, and 2.0 $\log _{10}$ CFU g ${ }^{-1}$, respectively, after the first composting cycle (Figures 4A-C). After the compost was mixed and moistened, numbers of viable $B$. anthracis spores generated at all three temperatures continued to decline, with reductions of $2.5,2.2$, and $2.8 \log _{10} \mathrm{CFU} \mathrm{\textrm {g } ^ { - 1 }}$ at 15,21 , and $37^{\circ} \mathrm{C}$, respectively (Figures 4A-C).

\section{DISCUSSION}

Passively aerated laboratory-scale composters (Xu et al., 2010) were used to study the composting of $B$. anthracis under containment conditions. In this study, physicochemical changes in compost over the experimental period were similar to those that we have reported in previous studies (Xu et al., 2010, 2013, 2014), demonstrating that our laboratory-scale composters were appropriate as a model for examining the ability of composting to inactivate $B$. anthracis spores. Using the same model, our laboratory has investigated the degree of degradation of scrapie (Xu et al., 2013, 2014), CWD and BSE (Xu et al., 2014), showing a $1-3 \log _{10}$ reduction in these prions after two cycles of composting. In this study, our findings further demonstrate a 2-3 $\log _{10}$ reduction of $B$. anthracis spores after two cycles of composting. Due to biocontainment restrictions for field-scale composting of $B$. anthracis, it was necessary to first assess the inactivation of $B$. anthracis spores within biocontained laboratory composting systems.

Several techniques, alone or in combination, have been tested for the inactivation of Bacillus spores, including heating, radiation, UV treatment, chemicals, and high pressure (Roberts and Hoover, 1996; Setlow, 2006; Xing et al., 2014). The mechanisms involved in these inactivation methods are linked to physicochemical modifications of metabolism proteins, inactivation of critical enzymes essential for spore germination, accumulative DNA damage, breakdown of spore membrane permeability barriers, and flattening and lengthening of the spores (Cléry-Barraud et al., 2004; Coleman et al., 2010). Composting is a natural biological process involving decomposition and stabilization of organic matter within an aerobic environment. Achieving optimal temperatures in compost is critical to reducing the viability of Bacillus spores. The majority of pathogens in compost are rendered non-viable if exposed to temperatures above $55^{\circ} \mathrm{C}$ for an extended period of time (Kalbasi et al., 2006; Xu et al., 2009). Guidelines for composting from the Canadian Council of Ministers of the Environment (CCME, 2005) and the United States Environmental Protection Agency (USEPA, 1995) both suggest that the duration of exposure at or above $55^{\circ} \mathrm{C}$ should be at least 15 consecutive days within compost windrows and 3 consecutive days in confined or in-vessel composters. Our recent findings showed that sustained thermophilic temperatures for 78 of 150 days in a laboratory oven reduced the number of viable $B$. licheniformis and $B$. thurigiensis spores in cattle manure by $\geq 5 \log _{10}$ CFU g $g^{-1}$ (Stanford et al., 2016). In the present study, temperature profiles showed that compost temperature remained $\geq 55^{\circ} \mathrm{C}$ for an average of 7 days, resulting in $2-3$ $\log _{10} \mathrm{CFU} \mathrm{g}^{-1}$ reduction of $B$. anthracis spores in compost. Although temperatures did not exceed $55^{\circ} \mathrm{C}$ in the second 


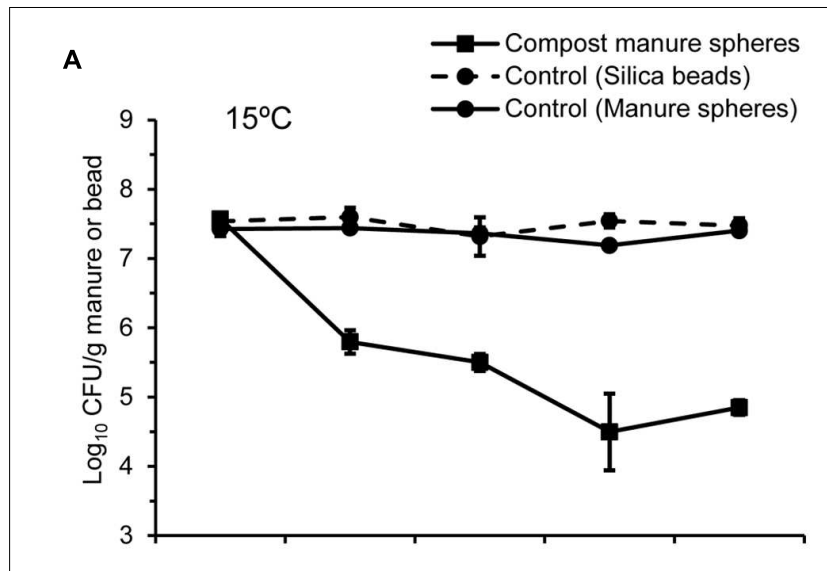

B

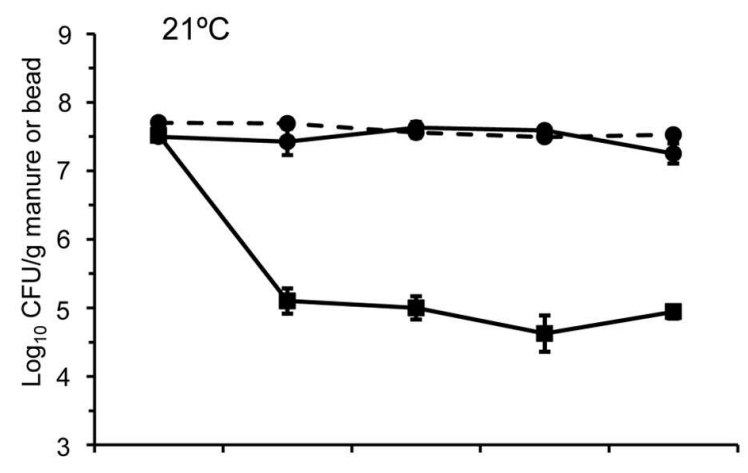

C

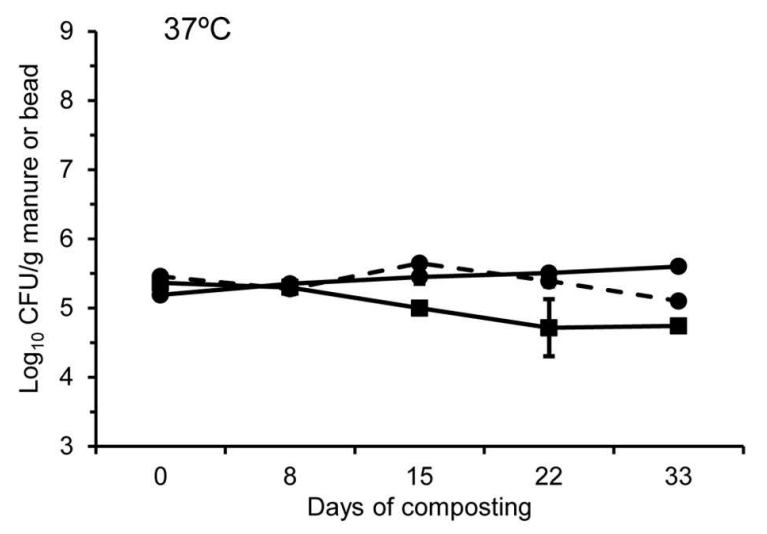

FIGURE 3 | Survival of $B$. thuringiensis spores $\left(\log _{10} \mathrm{CFU} \mathrm{g}^{-1}\right.$ manure) generated at different temperatures (A) $15^{\circ} \mathrm{C}$, (B) $21^{\circ} \mathrm{C}$, and (C) $37^{\circ} \mathrm{C}$ and placed in manure spheres that were composted with feedlot cattle manure for $\mathbf{3} 3$ days. For controls, silica beads and fresh manure spheres were inoculated with $B$. thuringiensis spores and kept at room temperature over 33 days. heating cycle, mixing and moistening of compost extended the period for inactivation of $B$. anthracis spores. However, the reduction of $B$. anthracis spores was lower in the second cycle as compared to the first cycle. Peak temperature was higher and the duration of exposure to thermophilic temperatures was longer in the first as compared to the second composting cycle,

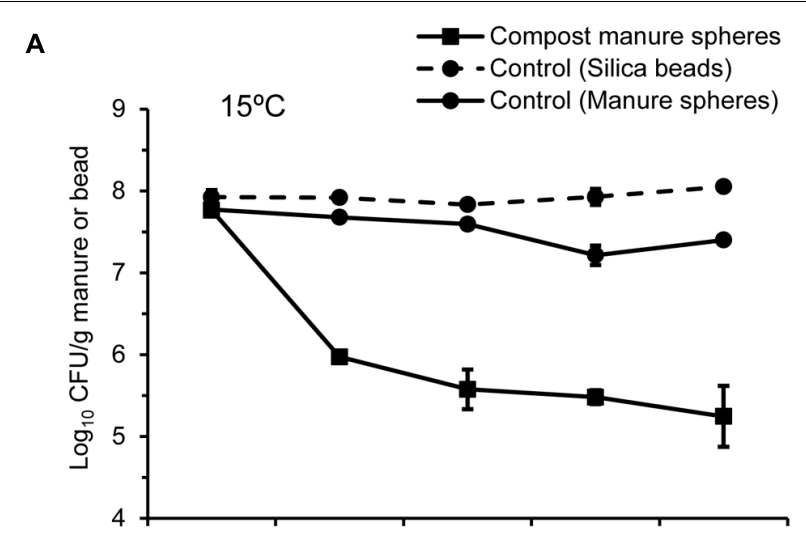

B

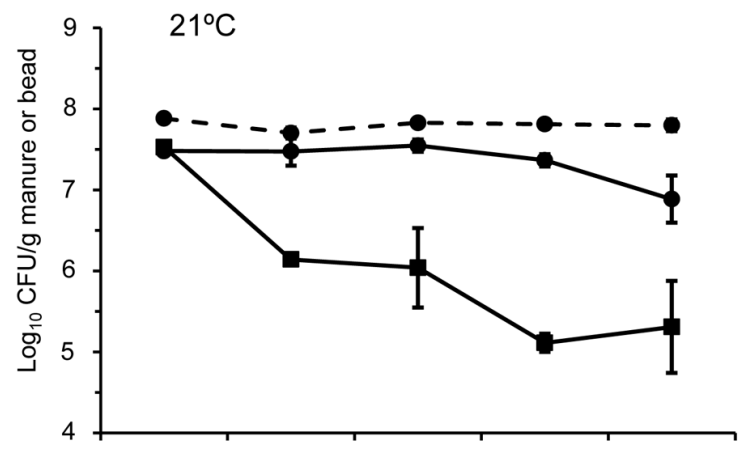

C

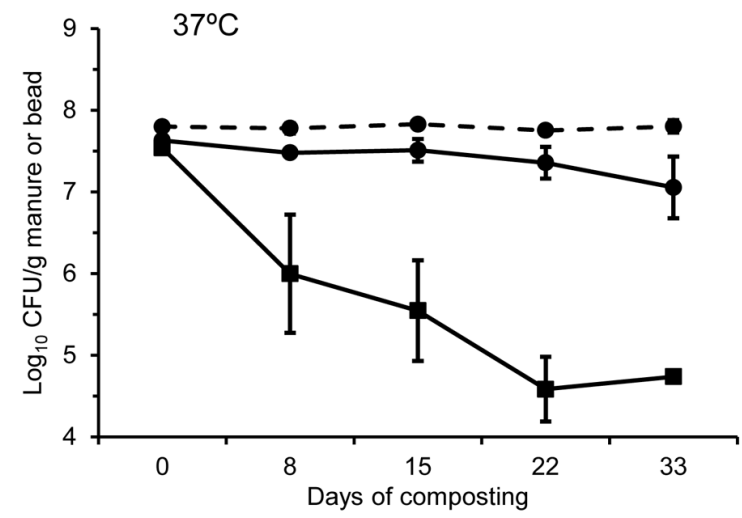

FIGURE 4 | Survival of $B$. anthracis spores ( $\log _{10} \mathrm{CFU} \mathrm{g}^{-1}$ manure) generated at different temperatures (A) $15^{\circ} \mathrm{C}$, (B) $21^{\circ} \mathrm{C}$, and (C) $37^{\circ} \mathrm{C}$ and placed in manure spheres that were composted with feedlot cattle manure for $\mathbf{3 3}$ days. For controls, silica beads and fresh manure spheres were inoculated with $B$. anthracis spores and kept at room temperature over 33 days.

suggesting that thermophilic compost temperatures $\geq 55^{\circ} \mathrm{C}$ were more effective at reducing spore viability than mesophilic temperatures. This is consistent with our previous results on the inactivation of $B$. cereus as a surrogate for $B$. anthracis during composting of cattle carcasses for 217 days (Stanford et al., 2015). 
Moreover, the duration of survival of Bacillus spores is lower when exposed to wet heat compared to dry heat, although the mechanisms for this phenomenon have not been fully elucidated (Nicholson et al., 2000). Our laboratory-scale compost remained moist (i.e., $\sim 76 \%$ moisture content; wet weight basis) as we added water to the compost after the first cycle. This approach likely increased the inactivation of Bacillus spores as compared to the scenario where dehydration would lead to a reduction in composting activity. Field scale compost piles consist of a heterogeneous matrix of organic matter with significant variation in moisture content within the mass, particularly with static composting ( $\mathrm{Xu}$ et al., 2009). The decline in spore viability may be less in regions of the pile where moisture levels are suboptimal for composting. In addition, $\mathrm{pH}$ has been reported to influence the heat resistance of Bacillus spores. Heat resistance is greatest at near neutrality $\mathrm{pH}$ and decreases under acid or alkaline conditions (Palop et al., 1999). Baweja et al. (2008) showed that the viability of $B$. anthracis Sterne spores was reduced by exposure to either acidic or alkaline chemicals. In this study, compost $\mathrm{pH}$ increased by more than 1.5 units to a $\mathrm{pH} \sim 9$, conditions that likely enhanced the inactivation of $B$. anthracis spores in compost.

Bacillus anthracis belongs to the $B$. cereus group along with B. cereus, B. mycoides, B. pseudomycoides, B. thuringiensis, and $B$. weihenstephanensis with which it shares many morphological, biochemical, and genetic similarities (Harrell et al., 1995; Maughan and Van der Auwera, 2011). Our laboratory has previously used $B$. cereus, $B$. licheniformis, and B. thuringiensis as surrogates for $B$. anthracis to assess the survival of $B$. anthracis spores during long term composting (i.e., 200 days) of cattle carcasses (Reuter et al., 2011; Stanford et al., 2015). Recent studies have shown that $B$. thuringiensis is gaining acceptance as the most suitable model for B. anthracis (Greenberg et al., 2010; Bishop and Robinson, 2014; Tufts et al., 2014). One of the genetic differences between these two species is that $B$. anthracis lacks a gene encoding a pleiotropic regulator, which is involved in sensing the external environment, activation of exoenzyme synthesis and other functions related to spore survival within the environment (Gohar et al., 2008; Bishop, 2014). However, this difference does not appear to result in differences between these two species in their ability to cope with environmental stresses, including dry heat, wet heat, and chlorination (Rice et al., 2005; Buhr et al., 2012; Setlow et al., 2014). Our results demonstrated that $B$. thuringiensis spores were inactivated in a manner similar to $B$. anthracis by composting, further supporting the use of $B$. thuringiensis spores as a model to assess the environmental robustness of $B$. anthracis spores.

To date, little is known about the effect of the sporulation temperature on survival of Bacillus spores during the composting process. Studies with various Bacillus species have shown that increasing the temperature during sporulation correlates with increased heat resistance of $B$. cereus (Collado et al., 2006), B. weihenstephanensis (Baril et al., 2011), B. licheniformis (Raso et al., 1995), and B. subtilis (Condon et al., 1992). However, this trend can be inconsistent among different strains within the same species (Fernandez-Coll and RodriguezToro, 1986; González et al., 1999), indicating that there are likely genotypic differences among strains that impact the heat resistance of Bacillus spores (Condon et al., 1992; Raso et al., 1995). Results in our study are consistent with Ignatenko et al. (1983) who reported that a rise in sporulation temperature from 20 to $35^{\circ} \mathrm{C}$ increased the thermal resistance of $B$. thuringiensis spores. For species of B. anthracis, Baweja et al. (2008) demonstrated that B. anthracis Sterne spores generated at $45^{\circ} \mathrm{C}$ were more resistant to wet heat than those sporulated at $25^{\circ} \mathrm{C}$. However, B. anthracis spores sporulated at temperatures as high as $37^{\circ} \mathrm{C}$ in the present study did not exhibit superior survival during composting as compared to those that were formed at lower temperatures. The complex environmental conditions during composting likely make temperature exposure only one of many factors that influence the viability of $B$. anthracis spores and it is possible that strains of $B$. anthracis differ in responses to these environmental challenges. Investigating the composting of endospores exposed to different sporulation temperatures is crucial, as it has important implications concerning decontamination protocols under various weather conditions (Condon et al., 1992; Palop et al., 1999). Our findings suggest that composting may be suitable for disposal of $B$. anthracis infected carcasses at geographical locations experiencing mild $\left(15-21^{\circ} \mathrm{C}\right)$ or hot $\left(>30^{\circ} \mathrm{C}\right)$ ambient temperatures. There is evidence that $B$. anthracis spores may undergo germination and growth in plant rhizosphere (Saile and Koehler, 2006) and may grow and amplify within amoebic hosts that remain viable outside of this temperature range (Dey et al., 2012).

To our knowledge, this is the first study describing the inactivation of $B$. anthracis spores as a result of composting. Limited biomass in the laboratory-scale composters resulted in thermophilic temperatures $\left(\geq 55^{\circ} \mathrm{C}\right)$ for only 7 days during two composting cycles over a period of 33 days. This contrasts with our previous field-scale system employed for investigation of the same strain of $B$. thuringiensis spores where temperatures $\geq 55^{\circ} \mathrm{C}$ were recorded for 75 days out of 230 days of composting (Reuter et al., 2011). These differences in duration of thermophilic temperatures were reflected in the degree of inactivation of $B$. thuringiensis spores with a $1-3 \log _{10}$ reduction in the laboratory composters after 33 days, as compared to a $\sim 5 \quad \log _{10}$ reduction within field-scale composters over 112 days (Reuter et al., 2011). Therefore, it is not unrealistic to expect a more extensive inactivation of $B$. anthracis spores during fieldscale composting. However, the complete inactivation of B. anthracis spores during composting is likely unrealistic. In practice, compost piles are affected by a number of internal and external factors including the heterogeneous nature of animal tissues and other matrix components that can result in fluctuating heat generation and distribution (Xu et al., 2009). Microbial communities that may play a role in the inactivation of spores may also differ among locations within the compost pile (Tkachuk et al., 2014). Consequently, further research is required to investigate the survival of B. anthracis spores in the microenvironments of compost piles where thermophilic temperature conditions may be compromised. 
In this study, B. anthracis Sterne, an attenuated nonencapsulated variant, was employed (Welkos and Friedlander, 1988). This strain does not have the pXO2 plasmid, which carries the capsule genes. However, all chromosomal genes responsible for sporulation and germination are present (Cléry-Barraud et al., 2004). Thus, spore components and spore resistance of this strain are assumed to be identical to those of the wild strain (Pézard et al., 1993). However, further comparisons of the difference in the survival of spores from the wildtype $B$. anthracis strain and Sterne strain may be required to assess the potential use of composting for disposal of $B$. anthracis infected carcasses. Furthermore, heat resistance of Bacillus spores is affected by the nature of matrix in which spores are heated (Coroller et al., 2001). Our findings showed that the numbers of viable $B$. anthracis spores in manure retained at room temperatures declined by $\sim 0.5 \log _{10}$ over 33 days while spores in the silica beads remained stable over the same time period. This suggests that the majority of the reduction in spore viability was associated with exposure to high temperatures, but microbial activity may have also contributed to this response. It is possible that the thermal resistance of $B$. anthracis spores originating from carcass exudate may differ from those composted in manure (Stanford et al., 2015). Future studies should evaluate the survival of $B$. anthracis spores in compost in the presence of animal tissues or fluids with various levels of fat, carbohydrate or proteins. However, we have previously shown that tissues other than ossified bones in bovine carcasses are completely degraded during field scale composting (Xu et al., 2009).

\section{CONCLUSION}

The composting should be considered as a simple method for on-site containment of infected carcasses in the event of an anthrax outbreak. The outcomes from this study showed a $3 \mathrm{log}$ inactivation of $B$. anthracis spores was achieved after 1 month of laboratory-scale composting. Further reductions in survival of B. anthracis spores are likely possible with field-scale composting

\section{REFERENCES}

Ala'Aldeen, D. (2001). Risk of deliberately induced anthrax outbreak. Lancet 358, 1386-1388. doi: 10.1016/S0140-6736(01)06492-3

Baril, E., Coroller, L., Postollec, F., Leguerinel, I., Boulais, C., Carlin, F., et al. (2011). The wet-heat resistance of Bacillus weihenstephanensis KBAB4 spores produced in a two-step sporulation process depends on sporulation temperature but not on previous cell history. Int. J. Food Microbiol. 146, 57-62. doi: 10.1016/j.ijfoodmicro.2011.01.042

Baweja, R. B., Zaman, M. S., Mattoo, A. R., Sharma, K., Tripathi, V., Aggarwal, A., et al. (2008). Properties of Bacillus anthracis spores prepared under various environmental conditions. Arch. Microbiol. 189, 71-79. doi: 10.1007/s00203007-0295-9

Beaumont, S. (2013). Mackenzie Wood Bison Update. Yellowknife, NT: Wekéezhiì Renewable Resources Board.

Bishop, A. H. (2014). Germination and persistence of Bacillus anthracis and Bacillus thuringiensis in soil microcosms. J. Appl. Microbiol. 117, 1274-1282. doi: $10.1111 /$ jam. 12620

Bishop, A. H., and Robinson, C. V. (2014). Bacillus thuringiensis HD-1 Cry-: development of a safe, non-insecticidal simulant for Bacillus anthracis. J. Appl. Microbiol. 117, 654-662. doi: 10.1111/jam.12560 as the duration of the thermophilic period is typically much longer. Although all $B$. anthracis spores might not be completely destroyed by composting, potential for the spread of these spores at infectious doses after composting would be reduced after land application due to both dilution and inactivation effects. Therefore, carcass composting might be considered as a viable method to reduce the dissemination of Bacillus spores to the surrounding environment.

\section{AUTHOR CONTRIBUTIONS}

SX: Designed/conducted laboratory experiments/first draft manuscript. AH: Designed/conducted laboratory experiment. RB: Conducted laboratory experiments. TR: Data analysis/contributed to manuscript. KA: Experimental design/laboratory facilities support for Level 3/funding of research activities. LS: Contributed to manuscript/experimental design. TM: Principal investigator for project/experimental design/finalized draft of manuscript/provided funding.

\section{FUNDING}

This research work was conducted with the funding from the Specified Risk Material Disposal Program of Agriculture and Agri-Food Canada.

\section{ACKNOWLEDGMENTS}

The authors acknowledge the Canadian and OIE Reference Laboratories for BSE at the Canadian Food Inspection Agency in Lethbridge, $\mathrm{AB}$ for providing the containment laboratory space to conduct the composting experiment. Many thanks to Ricki Fleming, Noriko Goji, Susan Druhan, George Wang, Fred Van Herk, Brant Baker, Albert Middleton, and Wendi Smart for their technical assistance.

Buhr, T. L., Young, A. A., Minter, Z. A., Wells, C. M., McPherson, D. C., Hooban, C. L., et al. (2012). Test method development to evaluate hot, humid air decontamination of materials contaminated with Bacillus anthracis Delta Sterne and B. thuringiensis Al Hakam spores. J. Appl. Microbiol. 113, 1037-1051. doi: 10.1111/j.1365-2672.2012.05423.x

CCME (2005). Guidelines for Compost Quality. Winnipeg, MB: Canadian Council of Ministers of the Environment.

CFIA (2013). Disposal of Anthrax Carcasses and Contaminated Materials. Ottawa, ON: Canadian Food Inspection Agency.

Cléry-Barraud, C., Gaubert, A., Masson, P., and Vidal, D. (2004). Combined effects of high hydrostatic pressure and temperature for inactivation of Bacillus anthracis spores. Appl. Environ. Microbiol. 70, 635-637. doi: 10.1128/AEM.70.1.635-637.2004

Cole, L. A. (2010). "Anthrax as a weapon of war and terrorism," in Bacillus Anthracis and Anthrax, ed. N. H. Bergman (Hoboken, NJ: John Wiley \& Sons Inc), 295-308.

Coleman, W. H., Zhang, P., Li, Y. Q., and Setlow, P. (2010). Mechanism of killing of spores of Bacillus cereus and Bacillus megaterium by wet heat. Lett. Appl. Microbiol. 50, 507-514. doi: 10.1111/j.1472-765X.2010.02827.x

Collado, J., Fernandez, A., Rodrigo, M., and Martinez, A. (2006). Modelling the effect of a heat shock and germination concentration on spore germination 
of a wild strain of Bacillus cereus. Int. J. Food Microbiol. 106, 85-89. doi: 10.1016/j.ijfoodmicro.2005.06.009

Condon, S., Bayarte, M., and Sala, F. J. (1992). Influence of the sporulation temperature upon the heat resistance of Bacillus subtilis. J. Appl. Bacteriol. 73, 251-256. doi: 10.1111/j.1365-2672.1992.tb02985.x

Coroller, L., Leguerinel, I., and Mafart, P. (2001). Effect of water activities of heating and recovery media on apparent heat resistance of Bacillus cereus spores. Appl. Environ. Microbiol. 67, 317-322. doi: 10.1128/AEM.67.1.317-322.2001

Dey, R., Hoffman, P. S., and Glomski, I. J. (2012). Germination and amplification of anthrax spores by soil-dwelling amoebas. Appl. Environ. Microbiol. 78, 8075-8081. doi: 10.1128/AEM.02034-12

Elkin, B., Armstrong, T., and Ellsworth, T. (2013). Athrax Emergency Response Plan (AERP) -Verstion 9. Yellowknife, NT: Government of the Northwest Territoires.

Erickson, M. C., Liao, J., Ma, L., Jiang, X. P., and Doyle, M. P. (2009a). Pathogen inactivation in cow manure compost. Compost. Sci. Util. 17, 229-236. doi: 10.1080/1065657X.2009.10702428

Erickson, M. C., Liao, J., Ma, L., Jiang, X. P., and Doyle, M. P. (2009b). Inactivation of Salmonella spp. in cow manure composts formulated to different initial C:N ratios. Bioresour. Technol. 100, 5898-5903. doi: 10.1016/j.biortech.2009. 06.083

Fernandez-Coll, F., and Rodriguez-Toro, W. (1986). Thermal resistance of spores of two species of the genus Bacillus. J. Agric. Univ. PR 70, 189-196.

Gohar, M., Faegri, K., Perchat, S., Ravnum, S., Økstad, O. E., Gominet, M., et al. (2008). The PlcR regulon of Bacillus cereus. PLoS ONE 3:e2793. doi: 10.1371/journal.pone.0002793

González, I., López, M., Martínez, S., Bernardo, A., and González, J. (1999). Thermal inactivation of Bacillus cereus spores formed at different temperatures. Int. J. Food Microbiol. 51, 81-84. doi: 10.1016/S0168-1605(99)00109-9

Greenberg, D. L., Busch, J. D., Keim, P., and Wagner, D. W. (2010). Identifying experimental surrogates for Bacillus anthracis spores: a review. Investig. Genet. 1, 4-16. doi: 10.1186/2041-2223-1-4

Guan, J., Chan, M., Grenier, C., Wilkie, D. C., Brooks, B. W., and Spencer, J. L. (2009). Survival of avian influenza and Newcastle disease viruses in compost and at ambient temperatures based on virus isolation and real-time reverse transcriptase PCR. Avian Dis. 53, 26-33. doi: 10.1637/8381-062008-Reg.1

Guan, J., Chan, M., Grenier, C., Wilkie, D. C., Brooks, B. W., Spencer, J. L., et al. (2010). Degradation of foot-and-mouth disease virus during composting of infected pig carcasses. Can. J. Vet. Res. 74, 40-44.

Harrell, L. J., Anderson, G. L., and Wilson, K. H. (1995). Genetic variability of Bacillus anthracis and related species. J. Clin. Microbiol. 33, 1847-1850.

Himsworth, C. G., and Argue, C. K. (2008). Anthrax in saskatchewan 2006: an outbreak overview. Can. Vet. J. 49, 235-237.

Hugh-Jones, M., and Blackburn, J. (2009). The ecology of Bacillus anthracis. Mol. Aspects Med. 30, 356-367. doi: 10.1016/j.mam.2009.08.003

Ignatenko, I., Sakharova, Z. V., Khovrychev, M. P., and Shevtsov, W. (1983). Effect of temperature and aeration on Bacillus thuringiensis growth and sporulation. Mikrobiologiia 52, 716-718.

Kalbasi, A. S., Mukhtar, S., Hawkins, S. E., and Auvermann, B. W. (2006). Design, utilization, biosecurity, environmental, and economic considerations of carcass composting. Compost. Sci. Util. 14, 90-102. doi: 10.1080/1065657X.2006.10702270

Levin, R. E. (2014). Anthrax: History, Biology, Global Distribution, Clinical Aspects, Immunology, and Molecular Biology. Oak Park, IL: Bentham Science Publishers.

Maughan, H., and Van der Auwera, G. (2011). Bacillus taxonomy in the genomic era finds phenotypes to be essential though often misleading. Infect. Genet. Evol. 11, 789-797. doi: 10.1016/j.meegid.2011.02.001

Nicholson, W. L. (2002). Roles of Bacillus endospores in the environment. Cell Mol. Life Sci. 59, 410-416. doi: 10.1007/s00018-002-8433-7

Nicholson, W. L., Munakata, N., Horneck, G., Melosh, H. J., and Stelow, P. (2000). Resistance to Bacillus endospores to extreme terrestrial and extraterrestrial environments. Microbiol. Mol. Biol. Rev. 64, 548-572. doi: 10.1128/MMBR.64.3.548-572.2000

Palop, A., Mañas, P., and Condón, S. (1999). Sporulation temperature and heat resistance of Bacillus endospores: a review. J. Food Saf. 19, 57-72. doi: 10.1111/j.1745-4565.1999.tb00234.x

Pézard, C., Duflot, E., and Mock, M. (1993). Construction of Bacillus anthracis mutant strains producing a single toxin component. J. Gen. Microbiol. 139, 2459-2463. doi: 10.1099/00221287-139-10-2459
Raso, J., Palop, A., Bayarte, M., Condón, S., and Sala, F. J. (1995). Influence of sporulation temperature on the heat resistance of a strain of Bacillus licheniformis (Spanish type culture collection 4523). Food Microbiol. 12, 357361. doi: 10.1016/S0740-0020(95)80116-2

Reuter, T., Alexander, T. W., and McAllister, T. A. (2011). Viability of Bacillus licheniformis and Bacillus thuringiensis spores as a model for predicting the fate of Bacillus anthracis spores during composting of dead livestock. Appl. Environ. Microbiol. 77, 1588-1592. doi: 10.1128/AEM.01889-10

Rice, E. W., Adcock, N. J., Sivaganesan, M., and Rose, L. J. (2005). Inactivation of spores of Bacillus anthracis sterne, Bacillus cereus, and Bacillus thuringiensis subsp. israelensis by chlorination. Appl. Environ. Microbiol. 71, 5587-5589. doi: 10.1128/AEM.71.9.5587-5589.2005

Roberts, C. M., and Hoover, D. G. (1996). Sensitivity of Bacillus coagulans spores to combinations of high hydrostatic pressure, heat, acidity and nisin. J. Appl. Bacteriol. 81, 363-368. doi: 10.1111/j.1365-2672.1996.tb01927.x

Saile, E., and Koehler, T. M. (2006). Bacillus anthracis multiplication, persistence, and genetic exchange in the rhizosphere of grass plants. Appl. Environ. Microbiol. 72, 3168-3174. doi: 10.1128/AEM.72.5.3168-3174.2006

Setlow, B., Parish, S., Zhang, P., Li, Y. Q., Neely, W. C., and Setlow, P. (2014). Mechanism of killing of spores of Bacillus anthracis in a hightemperature gas environment, and analysis of DNA damage generated by various decontamination treatments of spores of Bacillus anthracis, Bacillus subtilis and Bacillus thuringiensis. J. Appl. Microbiol. 116, 805-814. doi: $10.1111 /$ jam.12421

Setlow, P. (2006). Spores of Bacillus subtilis: their resistance to and killing by radiation, heat and chemicals. J. Appl. Microbiol. 101, 514-525. doi: 10.1111/j.1365-2672.2005.02736.x

Shields, M. J., Hahn, K. R., Janzen, T. W., Goij, N., Thomas, M. C., Bin Kingombe, C. I., et al. (2012). Immunomagnetic capture of Bacillus anthracis spores from food. J. Food Prot. 75, 1243-1248. doi: 10.4315/0362-028X.JFP-12-048

Smith, I. M. (1973). A brief review of anthrax in domestic animals. Postgrad. Med. J. 49, 571-572. doi: 10.1136/pgmj.49.574.571

Spencer, R. C. (2003). Bacillus anthracis. J. Clin. Pathol. 56, 182-187. doi: $10.1136 /$ jcp.56.3.182

Stanford, K., Harvey, A., Barbieri, R., Xu, S., Reuter, T., Amoako, K. K., et al. (2016). Heat and desiccation are the predominant factors affecting viability of Bacillus licheniformis and B. thuringiensis spores during simulated composting. J. Appl. Microbiol. 120, 90-98. doi: 10.1111/jam.12991

Stanford, K., Reuter, T., Gilroyed, B. H., and McAllister, T. A. (2015). Impacts of sporulation temperature, exposure to compost matrix and temperature on survival of Bacillus cereus spores during livestock mortality composting. J. Appl. Microbiol. 118, 989-997. doi: 10.1111/jam.12749

Stephens, C. (1998). Bacterial sporulation: a question of commitment? Curr. Biol. 8, R45-R48. doi: 10.1016/S0960-9822(98)70031-4

Sternbach, G. (2003). The history of anthrax. J. Emerg. Med. 24, 463-467. doi: 10.1016/S0736-4679(03)00079-9

Thappa, D. M., and Karthikeyan, K. (2001). Anthrax: an overview within the Indian subcontinent. Int. J. Dermatol. 40, 216-222. doi: 10.1046/j.13654362.2001.01174.x

Tkachuk, V. L., Krause, D. O., Knox, N. C., Hamm, A. C., Zvomuya, F., Ominski, K. H., et al. (2014). Targeted $16 \mathrm{~S}$ rRNA high-throughput sequencing to characterize microbial communities during composting of livestock mortalities. J. Appl. Microbiol. 116, 1181-1194. doi: 10.1111/jam.12449

Tufts, J. A. M., Calfee, M. W., and Lee, S. D. (2014). Bacillus thuringiensis as a surrogate for Bacillus anthracis in aerosol research. World J. Microbiol. Biotechnol. 30, 1453-1461. doi: 10.1007/s11274-013-1576-x

USEPA (1995). Decision Maker's Guide to Solid Waste Management. Washington, DC: United States Environmental Protection Agency.

Van Herk, F. H., Cockwill, C. L., Guselle, N., Larney, F. J., Olson, M. E., and McAllister, T. A. (2004). Inactivation of Giardia cysts and Cryptosporidium oocysts in beef feedlot manure compost by thermophilic windrow composting. Compost Sci. Util. 12, 235-241. doi: 10.1080/1065657X.2004.10702188

Wallin, A., Luksiene, Z., Zagminas, K., and Surkiene, G. (2007). Public health and bioterrorism: renewed threat of anthrax and smallpox. Medicina (Kaunas) 43, 278-284.

Welkos, S. L., and Friedlander, A. M. (1988). Pathogenesis and genetic control of resistance to the Sterne strain of Bacillus anthracis. Microb. Pathog. 4, 53-69. doi: 10.1016/0882-4010(88)90048-4 
World Health Organization (2008). Anthrax in Humans and Animals, 4th Edn. Geneva: World Health Organization.

Xing, Y., Li, A., Felker, D. L., and Burggraf, L. W. (2014). Nanoscale structural and mechanical analysis of Bacillus anthracis spores inactivated with rapid dry heating. Appl. Environ. Microbiol. 80, 1739-1749. doi: 10.1128/AEM.03483-13

Xu, S., McAllister, T. A., Leonard, J. J., Clark, O. G., and Belosevic, M. (2010). Assessment of microbial communities in decomposition of specified risk material using a passively aerated laboratory-scale composter. Compost Sci. Util. 18, 255-265. doi: 10.1080/1065657X.2010.10736964

Xu, S., Reuter, T., Gilroyed, B. H., Dudas, S., Graham, C., Neumann, N., et al. (2013). Biodegradation of specified risk material and fate of scrapie prions in compost. J. Environ. Sci. Health Part A 48, 26-36. doi: 10.1080/10934529.2012.707599

Xu, S., Reuter, T., Gilroyed, B. H., Mitchell, G., Price, L. M., Dudas, S., et al. (2014). Biodegradation of prions in compost. Environ. Sci. Technol. 48, 6909-6918. doi: $10.1021 /$ es500916v
Xu, W., Reuter, T., Inglis, G. D., Larney, F. J., Alexander, T. W., Guan, J., et al. (2009). A biosecure composting system for disposal of cattle carcasses and manure following infectious disease outbreak. J. Environ. Qual. 38, 437-450. doi: $10.2134 /$ jeq2008.0168

Conflict of Interest Statement: The authors declare that the research was conducted in the absence of any commercial or financial relationships that could be construed as a potential conflict of interest.

Copyright (c) 2016 Xu, Harvey, Barbieri, Reuter, Stanford, Amoako, Selinger and McAllister. This is an open-access article distributed under the terms of the Creative Commons Attribution License (CC BY). The use, distribution or reproduction in other forums is permitted, provided the original author(s) or licensor are credited and that the original publication in this journal is cited, in accordance with accepted academic practice. No use, distribution or reproduction is permitted which does not comply with these terms. 